\title{
NO BAÚ DE MIUDEZAS DE CIDINHA DA SILVA: \\ UMA ESCRITA AFROFEMININA BIOGRAFEMÁTICA E HOMOERÓTICA
}

\author{
Leila Cunba Raposo* \\ Valéria Amim ${ }^{* *}$
}

RESUMO: Em Baú de miudezas, sol e chuva, publicado em 2014, Cidinha da Silva, por meio de uma escrita afrofeminina, apresenta nas narrativas, ficção e traços biográficos entremeados, conduzindo às hibridas fronteiras dos gêneros discursivos e desvelando uma escrita também biografemática e homoerótica, tendo por base relações homoafetivas lésbicas entre mulheres negras. A partir dessas narrativas, objetivamos analisar a escrita afrofeminina, posto que defendemos que, entre os biografemas apresentados, há uma confluência entre as vivências biográficas da autora e sua escrita literária, bem como são revelados aos leitores pormenores que conduzem à temática homocultural, a par das relações lésbicas tematizadas. Pautamo-nos na apreciação teórico-crítica existente quanto aos estudos biográficos e homoculturais, bem como à literatura afro-brasileira. Como conclusões prévias desse estudo, realizado com metodologia qualitativa de caráter bibliográfico, acreditamos que os biografemas permitem entrever tanto a construção de um amor homoerótico feminino quanto discussões de gênero e etnia que perpassam pelo empoderamento de mulheres negras.

PALAVRAS-CHAVE: Estudos biográficos; Homocultura; Literatura Afro-Brasileira.

Baú de mindezas, sol e chuva (2014), escrito por Cidinha da Silva, é um livro que reúne narrativas de temáticas variadas, geralmente filiadas ao contexto político e social do Brasil, bem como a questões ligadas aos sentimentos e relacionamentos afetivos, incluindo os homoeróticos. A escritora mineira tematiza também, de forma contundente, o universo afro-

\footnotetext{
* Doutoranda em Literatura e Cultura na Universidade Federal da Bahia (Ufba).

** Professora Titular do Curso de Comunicação Social do Departamento de Letras e Artes da Universidade Estadual de Santa Cruz (Uesc). Doutora em Cultura e Sociedade pela Faculdade de Comunicação (FACOM) da Universidade Federal da Bahia (Ufba) e Pós Doutorado em sociologia pela Universidade da Beira Interior (UBI), Portugal.
} 
brasileiro, desde as religiões de matriz africana até uma abordagem que discute o racismo sofrido pelos negros, passando também por uma descrição de relações homoafetivas femininas entre mulheres negras. Assim, a cada crônica lida, é como se um tema, um simbólico objeto, fosse retirado do baú das miudezas da vida e ofertado aos leitores. Em meio às miudezas, constitui-se uma literatura afrofeminina que discute questões de gênero, etnia e cultura afro-brasileira, apresentando aos leitores mulheres negras que atuam de forma a rasurar perfomances tradicionalmente atribuídas a elas, tais como a dupla inferioridade de gênero (mulher e lésbica), de etnia e de processos de epistemícidio que insistem em atuar como uma forma de marginalização, supressão e subversão dos valores e saberes da cultura negra.

Desse modo, o presente estudo visa analisar, a partir da escrita afrofeminina apresentada nas narrativas de Cidinha da Silva em Baú de miudezas, sol e chuva (2014), os biografemas apresentados, seja com relação ao universo cultural da autora, seja no campo da homocultura. Para tanto, abordaremos, inicialmente, enquanto percurso de análise, uma apresentação de Cidinha e dos estudos biográficos, para, posteriormente, passarmos a uma análise com base na crítica biografemática e na literatura homoerótica, bem como na literatura afro-brasileira, no intuito de apresentarmos as múltiplas formas nas quais essas vertentes se entrelaçam nos textos da autora.

Destacamos que, no presente texto, entendemos por literatura afrofeminina a escrita literária de mulheres negras, em cujos textos se faz presente a marca autoral feminina, a qual delineia uma identidade afro-brasileira e práticas discursivas que apresentam as subjetividades relacionadas à cosmovisão, à cultura afro-brasileira, às africanidades, emoções e vivências, dentre outros pontos. Salientamos que tal apresentação se faz de modo afirmativo, crítico, cônscio da necessidade de problematizar questões étnicas, de gênero e socioculturais, perpassando, também, pelo âmbito subjetivo do espaço biográfico que compõe o universo literário, conforme pontua Conceição Evaristo (2011b).

No cenário da literatura contemporânea brasileira, Cidinha da Silva se destaca como umas das mais atuantes prosadoras, com publicações nas modalidades da crônica, do 
teatro, da literatura infanto-juvenil e, também, com textos que fogem ao ficcional e abordam o racismo, bem como a cultura afro-brasileira, especialmente vinculados à temática da educação. A escritora mineira, em seus textos, não foge à sua condição de mulher negra e, de forma muito específica, atua na realidade social a partir da assunção dessa identidade, inclusive religiosa e ancestral. De acordo com a crítica e pesquisadora Constância Lima Duarte (2014, p. 457),

Cidinha da Silva [...] tem uma trajetória marcada por intensa militância nos movimentos voltados para a inclusão social da população afrodescendente. Em São Paulo, onde residiu por 17 anos, coordenou o Programa de Educação do Geledés - Instituto da Mulher Negra, tendo ocupado também a presidência da organização, que, ao lado das dezenas de grupos de mulheres negras espalhados pelo país, acrescenta um instigante suplemento de gênero à prática política do Movimento Negro.

A partir do que nos fala Constância Duarte, é possível entendermos que as vivências de Cidinha, enquanto mulher e negra, inspiram também suas narrativas, como observamos em "O fogo, têmpera do aço, o tempo, têmpera das gentes". Nessa crônica, a autora retoma o período em que ela ainda morava em Minas Gerais e foi convidada a trabalhar em São Paulo, no Geledés ${ }^{1}$, por Sueli Carneiro:

Sueli Carneiro me fez nascer pela segunda vez, quando, atendendo a um pedido meu, convidou-me para trabalhar e viver em São Paulo. E por isso me sentirei grata em todas as vidas que me for dado viver. E grata também pelas lições aprendidas via Método SC. [...] Sueli, como a sinto, é essência de ferro, vento, ouro e amor de mãe (SILVA, 2014, p. 96) ${ }^{2}$.

\footnotetext{
${ }^{1}$ O Instituto foi fundado em 30/04/1988. É uma organização civil que se posiciona em defesa das mulheres negras e de homens negros, combatendo o racismo e o sexismo vigentes na sociedade brasileira. Site <https://www.geledes.org.br/geledes-missao-institucional/>. Acesso em: 26/009/2017.

${ }^{2}$ SILVA, Cidinha da. Baú de miudezas, sol e chuva: crônicas. Belo Horizonte: Mazza Edições, 2014. Todas as demais citações foram retiradas dessa edição, passando-se apenas a indicar BM em referência ao título, com o número das respectivas páginas.
} 
Diante da importância de Sueli Carneiro na vida de Cidinha, conforme observamos pela citação da autora mineira, cabe nos informar ao leitor sobre quem é essa mulher que tanto ensinou à cronista. Sueli Carneiro é doutora em educação pela Universidade de São Paulo - USP e uma das fundadoras do Geledés - Instituto da Mulher Negra, a primeira organização negra e feminista independente de São Paulo. A atuação dela se destaca pelo combate ao racismo e também por suas atividades voltadas às mulheres negras, visto que ela criou o único programa brasileiro de orientação na área de saúde física e mental específico para mulheres afrodescendentes, o qual oferece assistência psicológica e social a mais de trinta mulheres por semana. Quando vemos os ramos de atuação de Sueli, é possível deduzirmos, então, o quanto ela representa um símbolo para a prosadora mineira por todas as vertentes identitárias que as aproximam³.

Em "O fogo, têmpera do aço, o tempo, têmpera das gentes", ao discutir comportamento e de que forma o tempo molda e acomoda situações e sentimentos nas pessoas, a partir das suas vivências ao lado de Sueli Carneiro, a escritora retoma trechos de sua vida que rememoram a descrição biográfica feita por Constância Duarte (2014). Ainda nessa crônica, Cidinha (2014) diz que os caminhos da vida a levaram a se reaproximar da literatura e se reiventar. Ou, como diz Duarte (2014, p. 458), “foi necessário transitar do 'ativismo' para o 'artivismo' e traduzir a consciência do pertencimento étnico-racial e a visão crítica a ela inerente, em termos propriamente literários".

Desse modo, é possível entendermos que os assuntos do Baú de mindezas de Cidinha são também compostos por suas experiências pessoais ou, como nos diz Conceição Evaristo (2011b), pela condição subjetiva de ser mulher e negra que se traduz na escrita feminina afro-brasileira. De acordo com a cronista Cidinha da Silva, "essa reinvenção faço-a

${ }^{3}$ Informações extraídas do site da Fundação Palmares. Site: <http://www.palmares.gov.br/?p=26674>. Acesso em: 20 de maio de 2016. 
nas crônicas diárias, nos livros [...]. Minha cidade e minha família me deram régua e compasso. Sueli me deu uma tela ampla para xilografar minha história” (BM, 2014, p. 99). Não caímos aqui na ideia de reduzir os textos da escritora mineira a simples relato de experiências biográficas, desprezando o seu primordial caráter literário da ficção narrativa, muito pelo contrário. Desejamos sim observar o modo como as narrativas da autora se entrecruzam ao espaço biográfico e originam os textos, num flerte entre o literário e as vivências pessoais.

De acordo com Leonor Arfuch (2010, p. 32), o espaço biográfico “operará, prioritariamente, como ordem narrativa e orientação ética nessa modelização de hábitos, costumes, sentimentos e prática, que é constitutiva da ordem social”. Assim, observarmos que, nas crônicas apresentadas em Baú de miudezas, sol e chuva, as experiências pessoais da autora desse livro direcionam ética e etnicamente as narrativas ali, visto que há o delineamento da cultura afrodescendente explorada em suas múltiplas perspectivas, inclusive religiosa, como também o de gênero, a partir da condição de ser/estar da mulher negra no mundo e da temática do amor lésbico.

Ademais, quando falamos das aproximações entre os campos discursivos literatura e espaço biográfico, retomamos a noção de que "os estudos histórico-biográficos contemporâneos têm em mente as relações entre acontecimentos, conjunturas e estruturas, elites e massas, indivíduos e grupos, palavra e ação” (MITIDIERI, 2014, p. 98). Desse modo, na conformação desses espaços de entrecruzamentos, "vidas vividas juntam-se a sinais diversos, imagens, resíduos sígnicos, também a indagarem sobre a realidade", conforme analisa Mitidieri (2014, p. 98) e que nos permite chegar à noção de biografema.

Em Sade, Fourier, Loyola, o filósofo Roland Barthes apresenta o termo biografema numa referência ao modo como gostaria que a sua vida fosse narrada:

Se eu fosse um escritor, já morto, como gostaria que minha vida se reduzisse, pelos cuidados de um biógrafo amigo e desenvolto, a alguns pormenores, a alguns gostos, a algumas inflexões, digamos: 'biografemas', cuja distinção e mobilidade poderiam viajar fora de qualquer destino e vir tocar, à maneira dos átomos epicurianos, algum 
corpo futuro, prometido à mesma dispersão (BARTHES, 1990, p. 12).

Podemos compreender, então, que o biografema diz respeito aos pormenores, aos pequenos detalhes que revelam traços de personalidade do sujeito e que são, assim, transpostos às narrativas de modo esparso e fragmentado. Desse modo, “o caráter não linear do biografema fundamenta-se na mobilidade e na fluidez, oferecendo sinais entrecortados que proporcionam a materialização ou as interpretações da multiplicidade do indivíduo e das sociedades" (MITIDIERI, 2014, p. 100). Ademais, quando observamos o trecho "é esta mulher que escolho para me fazer quem quero ser" (BM, p. 97), sendo que o "esta mulher" refere-se a Sueli Carneiro, podemos entender que esse texto perpassa pelo âmbito do subjetivo, da relação autor-sujeito transposta à narrativa literária. Isso porque é possível observarmos que há uma confluência entre a identidade subjetiva da autora (mulher, negra, admiradora de Sueli Carneiro) com as experiências do eu narrativo, o qual, nesse momento, assume características muito próximas às da escritora Cidinha.

Por sua vez, em "Como o Jazž", crônica inicial de Baú de mindezas, sol e chuva, o eu narrativo relata seu encontro com um menino que, aparentemente, era fã dos livros escritos por esse narrador sem gênero demarcado. Ainda que o jovem nunca tivesse feito objetivamente nenhum elogio mais explícito sobre o quanto gostava dos livros, numa conversa entre os dois, o menino diz "Seu texto é negro como o jazz?" (BM, p. 15 - grifo da autora). A partir daí, o eu narrativo comenta: "Aquilo me deu outra vida, e eu a vivi como o cello de Yo-Yo Ma ecoando nas paredes do oco do mundo” (p. 15 - grifo da autora). Aqui, vemos como um biografema tanto a referência ao jazz, importante ritmo musical para a cultura negra, quanto a Yo-Yo Ma, músico francês de ascendência chinesa que ultrapassou muitas fronteiras culturais e geográficas para mostrar sua arte e ser reconhecido por isso, entendendo que essas alusões compõem também o imaginário subjetivo do mundo particular de Cidinha da Silva. Ademais, é fator significante que esse trecho esteja na primeira crônica do livro, pois é possível entendê-lo também como uma chancela a autorizar a experiência de Cidinha enquanto prosadora. 
Já em "Doce", encontramos também mais biografema "musical", o qual alude à beleza e ao talento de origem afro: "Ouvir Suzana, la cantante afro-peruana, traz de volta tua gargalhada, tua voz de barítono pela manhã, o repertório de boleros escolhido a dedo, condição para preparar-te o café" (BM, p. 38 - grifo da autora). Na narrativa, quando a narradora ouve a cantora afro-peruana Suzana, ela relembra de uma ex-namorada imigrante que lhe desperta saudades. Na intimidade dominical matutina, era condição essencial que a imigrante cantasse em espanhol crioulo para que a narradora preparasse um café da manhã para a namorada.

Com a referência a Suzana Baca, ilustre cantora afro-peruana e primeira mulher negra a assumir um cargo político no Peru, observamos, conjuntamente ao visual da imigrante - "com teus dreads espetados, recém-nascidos, que tu querias em queda, de imediato" (BM, p. 38) - que a relação homoerótica se constrói no texto em torno de um ideal de valorização da cultura e da beleza negra. O sentido atribuído ao cabelo afro, "os dreads", assume para além do caráter estético, um estilo político, afirmativo, de militância e de representação cultural, religiosa, social e ideológica, de uma expressão criada no interior da comunidade negra: a beleza negra, tornando-se um ícone na construção da identidade negra. Representa, ainda, um sentimento de autonomia, expresso nas formas ousadas e criativas de usar o cabelo (GOMES, 2006).

Da mesma forma, destacamos a referência a Suzana, enquanto uma mulher negra bem-sucedida, empoderada e empoderadora, como um ícone identitário positivo da cultura negra. Esse conjunto de referências nos permite observar o entrecruzamento entre campos discursivos diversos, a partir dos quais se aproximam as temáticas do homoerotismo, o espaço biográfico (com base no posicionamento de Cidinha enquanto mulher negra "artivista") e a cultura afro-brasileira (especificidade que, pela forma como é construída, filia o texto à literatura afro-brasileira, em especial, à escrita afrofeminina).

\footnotetext{
${ }^{4}$ Foi no movimento rastafari que os dreads ganharam visibilidade, embora anos antes, alguns grupos étnicos do Norte e Leste da África já usassem dreadlocks.
} 
Por sua vez, em “Eu sou coluna de aço! Se quer passar, arrodeia!”, o eu narrativo, também feminino e negro, louva o fato de Mãe Stella de Oxóssi assumir uma cadeira na Academia de Letras da Bahia. A propósito do fato, é comentado: "finalmente, a Academia de Letras da Bahia, composta pela elite tradicional branca baiana dobrou os joelhos à realeza nagô, à realeza manifesta nos 87 anos da Iyalorixá Stella de Oxóssi!” (BM, p. 86). Ao sentar em uma cadeira na Academia de Letras da Bahia, sentam-se com Mãe Stella a sua linhagem ancestral e seu mundo, posto que, nas religiões de tradição africana, a herança ancestral é inseparável da linhagem do indivíduo, e continua a viver através dele, constituindo-se seu prolongamento e conferindo, dessa maneira, sua continuidade.

O enaltecimento em torno dessa ialorixá baiana indicia que ela é um modelo para o eu narrativo, transitando entre o biografema, no campo das subjetividades que compõem o mundo de Cidinha da Silva enquanto autora, e um símbolo de resistência, força e sabedoria da cultura afro-brasileira. Não à toa, Mãe Stella aparece em mais duas crônicas de Baú de mindezas, sol e chuva.

Essa descrição positiva em torno da figura do afrodescendente, e, em especial, de mulheres negras que se destacam, bem como da cultura negra, representa também uma das diretrizes da literatura afro-brasileira, a qual visa à representação da cultura afro-brasileira de modo afirmativo e enaltecedor. Essa característica, aliada a outras, firma Cidinha da Silva entre os principais nomes desse segmento literário brasileiro na atualidade, conforme aponta a pesquisadora Constância Lima Duarte (2014). É forçoso reconhecer que esse campo literário ainda encontra muitas resistências para ser aceito e considerado como um sistema literário válido, com características próprias, em especial no âmbito acadêmico. Contudo, de acordo com Conceição Evaristo (2011a, p. 50 - grifo da autora),

Principalmente nas últimas três décadas, se afirma, no interior da Literatura Brasileira, um discurso específico, que fratura o sistema literário nacional em seu conjunto. São textos literários em que o corpo negro deixa de ser o corpo do 'outro' como objeto a ser descrito, para se impor como sujeito que se descreve, a partir de uma subjetividade experimentada como cidadão/ã negro/a na sociedade brasileira. 
No tocante à formação e consolidação, Eduardo de Assis Duarte (2008, p. 12) afirma que, ainda que esse campo literário esteja em processo de afirmação acadêmica, é possível observar que "algumas constantes discursivas se destacam e têm sido utilizadas como critérios de configuração dessa literatura". Assim, o pesquisador elenca cinco características as quais, imbricadas, indicam uma filiação a essa vertente literária: temática em torno do negro, descrito enquanto sujeito plural, autônomo e senhor de sua subjetividade; a autoria, advinda de um autor afro-brasileiro; o ponto de vista, com o assumir de uma defesa quanto à cultura negra, especialmente identificando-se como pertencente a essa cultura; a linguagem, com a inserção de elementos referentes ao cruzamento das línguas portuguesa e africanas; e, por fim, a formação de um público leitor afrodescendente.

A partir dessas características apontadas pelo pesquisador Eduardo Assis Duarte, podemos observar que a escrita de Cidinha apresenta, no conjunto de sua obra, tais aspectos, inclusive quanto à linguagem, conforme observamos no seguinte trecho: "E agradecer, enquanto descanso a cabeça em seu colo e me refaço no cafuné. Nzqaambi ye kwaatesa" (BM, p. 16 - grifo da autora). Esse fragmento encerra a crônica "Minha Senhora das Águas" e é um pedido/desejo de proteção comumente utilizado no candomblé angola, religião que, por suas influências, traz uma relação linguística com a África. A expressão seguida a Nraambi ye kwaatesa é aueto, que reafirma a proteção divina de Zambi, entidade soberana que representa o Ser Criador nos terreiros Angola-Congo.

Essa cosmovisão integrava de forma indelével a cultura dos negros escravizados conhecidos no Brasil como Angola, Congo, Benguela, Monjolo, Cabinda, Rebolo, provenientes da região Angola-Congo durante os séculos XVI até ao XIX. Entre o final do século XVIII e o início do século XIX, os negros e negras escravizados de origem daomeana, chamados jejes e os/as de origem nagô- iorubá foram introduzidos em massa na Bahia. Essa introdução tardia, se comparada com a dos grupos étnicos anteriores, explica a forte predominância dos iorubás, de seus usos e costumes na Bahia, além de sua resistência às influências culturais dos senhores. É sabido que entre os iorubás havia sacerdotes que eram 
"conscientes do valor de suas instituições e firmemente ligados aos preceitos de sua religião” (VERGER, 2002, p.27). Essa diversidade étnica africana e suas expressões religiosas e culturais afirmam uma escrita que se espelha nos ancestrais mitos africanos dos orixás, mantidos vivos e alterados no cotidiano da sociedade contemporânea e, desse modo, transformados em mitos afro-brasileiros.

Assim, não raro, observamos em Baú de miudezas, sol e chuva a utilização de palavras e/ou expressões de línguas africanas, como acontece também na crônica "Duas mulheres numa rua íngreme", de temática homoerótica: "Em dado momento, a mulher de Yansã vê o fio de contas da motorista sobre a mesinha do abajur e o saúda: 'Saluba, viu, Xangô?' A outra ri e explica: 'É herança, preta!"' (BM, p. 33). A saudação iorubá "Saluba", saudação de Nanã, está no trecho final dessa crônica que, ao longo do seu desenvolvimento, dentre outros temas, discutirá a filiação religiosa das duas personagens principais e a relação destas personagens com suas identidades míticas, com constantes evocações à herança religiosa africana, inclusive a linguística.

Observamos, então, que no campo da escrita identidades mafrofeminina de Cidinha da Silva, os biografemas referentes ao universo biográfico de Cidinha da Silva e ao campo do homoerotismo constituem-se também pelas escolhas lexicais das personagens, as quais tanto evocam memórias de línguas ancestrais quanto encontram a comunhão amorosa que se reconhece identitariamente na fala dos seus pares. Cidinha da Silva desperta questões que tocam no mais íntimo do ser humano, descrevendo situações de homens e mulheres no mundo em que vivem, porque a memória das línguas ancestrais integra a religião e só faz sentido frente à realidade da vida, com suas tristezas e alegrias.

Assim, entendemos que essa escrita afrofeminina traduz o processo de autoria de um corpo negro que se inscreve e que fala por si, a partir da sua subjetividade, o que é de fundamental importância, seja pela resistência que expressa, seja pela necessidade de desconstruir discursos historicamente engendrados e consagrados com base numa cultura hegemônica branca. De modo mais específico, quanto à subjetividade expressa nos textos, 
Conceição Evaristo avalia que não há como desvencilhar a escrita literária do caminho biográfico percorrido por esse sujeito negro e observa, tendo como referente sua escrita:

[...] quando escrevo, quando invento, quando crio a minha ficção, não me desvencilho de um corpo-mulher-negra em vivencia e que, por ser esse o meu corpo, e não outro, vivi e vivo experiências que um corpo não negro, não mulher, jamais experimenta (EVARISTO, 2011b, p. 132 - grifos da autora).

Ao pontuar sobre a escrita que traz uma subjetividade feminina e étnica, Evaristo (2011b) nos oferece condições para analisar o texto de Cidinha, enquanto escritora negra, em cujas narrativas apresenta personagens que representam a condição de mulheres afrodescendentes, nos mais diversos contextos, numa confluência de possíveis identificações entre a vida dessas mulheres e a da autora, também na condição de mulher e negra. Muitas delas são, também, lésbicas e, assim, há uma ampliação das questões de gênero, as quais se unem ao componente étnico. Do mesmo modo que a literatura afro-brasileira discute questões relativas a uma minoria que esteve/está à margem da sociedade, concedendo voz a esses sujeitos, a literatura homoerótica também traz, em seu bojo, discussões relativas a um outro grupo historicamente marginalizado - os homossexuais, conforme observamos em "Duas mulheres numa rua íngreme".

Nessa narrativa ocorre, de forma casual, um encontro amoroso entre duas mulheres negras. Uma delas está saindo de carro com duas amigas quando vê outra mulher, de beleza estonteante, caminhando pela rua e comenta com as suas acompanhantes que aquela moça só poderia ser filha de Iansã - “'Ousada desse jeito só pode ser de Iansã” (BM, p. 32). Disposta a tirar a dúvida e, também, interessada na moça, a motorista decide se aproximar, conforme observamos no trecho a seguir:

Motorista habilidosa, a moça do carro vermelho, dirige coladinho nela e mansa, doce, diz à semi-deusa: 'Boa tarde, senhora dos ventos, da tempestade que tumultua meu peito. Permita que eu me apresente. Eu sou o Xangô que Oyá mandou para guardar seu caminho. Dê-me a honra de acompanhá-la em seu destino' (BM, p. 32). 
A partir da sensual e doce cantada que a pedestre ouve, ela analisa o interior do carro e aceita a carona - ação primordial para o início do encontro amoroso entre as mulheres numa tarde de passeios, com direito a parada para o sorvete, e que culminou numa visita da motorista à casa da moça que andava na rua: "é convidada a entrar e, papo vai, papo vem, musiquinha, carinho, janelão para mirar o Sol se pondo atrás do mar e o tempo parece correr lento" (BM, p. 33). Nessa crônica, observamos que há uma subversão de situações tradicionalmente masculinas, como a do homem que pára o carro para cantar uma mulher na rua, e, com isso, ocorre uma rasura nos papeis tradicionalmente "pré-definidos”, como também há uma atribuição de doçura e naturalidade a eles, sem perder a tônica sensual homoerótica da relação que se estabelece entre as duas mulheres negras.

Ao longo de Baú de mindezas, sol e chuva, a temática homoerótica se apresenta por meio da representação de um amor feminino, no qual ora o encontro entre as mulheres se dá de forma mais doce, ora mais velada e, em outras, mais explicitamente sensual. Nesses textos, mulheres das mais diversas condições e papéis, contudo, em sua maioria, negras e lésbicas, compõem o imaginário dessas relações homoafetivas descritas. Essa temática, constantemente abordada por Cidinha da Silva, conforme aponta Constância Duarte (2014), também possibilita que a escrita da prosadora mineira vincule-se à literatura homoerótica ou de temática gay. De acordo com o pesquisador Antonio Dias Silva (2009, p. $100)$,

A literatura gay ou literatura/escrita/texto de temática gay é definida pela escolha do tema, pelo posicionamento das personagens, que atuam nas narrativas como gays [...]; os desejos ali representados são prioritariamente homoafetivos, uma vez que as personagens centrais destas narrativas entram em conflito com a realidade da sociedade de base heterossexual cristã, machista, misógina e homofóbica que impõe uma norma geradora de tensão entre os diferentes grupos.

Em consonância com essa conceituação apresentada por Silva, podemos observar que a escrita da cronista mineira se alia à literatura de temática homoerótica não só pela representação de um amor lésbico em si, mas também pelo comportamento assumido pelas 
personagens, as quais enfrentam a lógica heteronormativa e machista. Um exemplo disso é a subversão expressa em "Duas mulheres numa rua íngreme", na qual há não só a apropriação da motorista de um comportamento tipicamente masculino, como a transformação desse ato em uma ação realizada de forma doce e sensual. Observamos que ocorre, dessa forma, um jogo com as performatividades tradicionalmente atribuídas aos gêneros, rasurando seus papeis ao deslocá-los. Ademais, a lógica heteronormativa é, no texto, de modo sutil, vencida pelas mulheres.

No início da crônica, o trecho "A torcida inconfessável dos homens era para que a saia se desfizesse" (BM, p. 31) nos permite observar que há uma plateia masculina desejosa em relação à pedestre, cujo desejo não se importava de que a moça ficasse exposta na rua, com uma saia levantada ou desfeita, estando apenas de calcinha, mas sim que houvesse o prazer para os homens que a olhavam. Contudo, "a gata também contava com torcida feminina” (BM, p. 31). Nesse "jogo de torcidas", representativo de uma ordem heteronormativa e machista, quem ganha são as mulheres, pois é a motorista quem aborda a pedestre e não só dá carona a ela, como também as duas se relacionam homoeroticamente, frustrando duplamente a torcida masculina.

Nessa narrativa, o componente étnico se faz presente não só pelas personagens serem negras, mas, em especial, pela afirmação positiva em torno da cultura afro-brasileira. Ao ser narrado o desejo dos homens, há uma descrição de como eles queriam que a pedestre ficasse, caso a saia levantasse: "a bela ficasse apenas com a blusa laranja de alças delicadas, as sisterlocks em leve desalinho e o salto 12” (BM, p. 31 - grifo da autora). Notamos que, para além do componente sensual da cena, a mulher é descrita como bela e há a referência "sisterlocks", que indica cabelos no estilo dreadlocks, valorando de modo positivo a beleza negra, assim como ocorreu na referência aos cabelos dreadlocks de uma das personagens de "Doce". Coincidentemente ou não, biografematicamente ou não, a autora Cidinha da Silva também usa o seu cabelo trançado, como uma das modalidades dos dreadlocks. E com isso indicamos que esse ideal de beleza permeia o universo do qual ela faz parte. 
Ademais, em muitos trechos, há um entrelaçar de características atribuídas aos Orixás num correlativo com as personagens descritas. Em passagens como "É de Iabá! Não tenho dúvidas. Não é de Iemanjá, de Naña, nem de Obá. Se fosse de Oxum teria mais dois dedos de saia" (BM, p. 31) e "Boa tarde, senhora dos ventos, da tempestade [...]. Eu sou o Xangô que Oyá mandou para guardar seu caminho” (BM, p. 32), observamos que há, por exemplo, uma tentativa de identificar a filiação religiosa da pedestre correlacionando suas atitudes às identidades míticas dos Orixás e suas características, biografema que remete à compreensão da dinâmica de integração entre o personagem e a transcendência. Temos de um lado, bem marcado as entidades femininas, as iabás, que possuem como símbolo "uma cabaça com um pássaro dentro, representando o ventre fecundado. São as poderosas depositárias dos mistérios da gestação” (AUGRAS, 2008, p.59). A Senhora dos Ventos imagem costumeiramente ligada a Iansã, nos remete aos mais variados sentidos e expressões contidos em Omo Inã (outra maneira de se referir a Iansã), a filha do fogo que é livre e violenta como a tempestade, que ela comanda. Iansã revela a sua dupla origem, de água e de fogo, que a torna símbolo da união de forças opostas.

De outro lado, a relação existente entre uma sexualidade mítica e uma sexualidade humana, não parece ser um problema para as religiões afro-brasileiras, já que as histórias dos orixás são usadas como forma de explicar os papeis sexuais, tanto no terreiro quanto nas atividades ordinárias do cotidiano. A reprodução ou reinterpretação do discurso hegemônico da sociedade sobre os papeis sociais relacionados aos gêneros, à sexualidade e ao seu exercício estão, portanto, implícitos nos sistemas simbólicos (FRY, 1982). O que significa que as identidades bem como os papeis sexuais, nas religiões afro-brasileiras e, consequentemente, em seus espaços de existência, os terreiros, estão inscritos no domínio do social e do cultural, logo, são móveis, fluídos tal qual a vida em sociedade.

Os biografemas que fazem parte do universo religioso transitam em outras narrativas presentes em Baú de miudezas, sol e chuva. Dessa forma, são revelados pormenores biográficos e homoculturais que compõem o subjetivo universo cultural de Cidinha, em espe- 
cial no que tange às memórias ancestrais da cultura negra e de relações homoafetivas lésbicas narradas de modo positivo, sem o peso de um julgamento moral ou de uma conotação pejorativa. Ao contrário, as relações são, como devem ser, representadas de uma maneira natural e positiva.

Nesse sentido, o texto literário deixa de ser apenas fruição estética e assume também o valor e a função de "demover lugares antes solidamente cimentados numa ou por uma cultura heteronormativa conservadora e perceber como personagens-sujeitos avançam nas relações sociais de poder" (SILVA, 2014, p. 62). É significativa a vitória feminina apresentada em "Duas mulheres numa rua íngreme", bem como o ideal de beleza negra e a apresentação afirmativa da cultura afro-brasileira, não só em razão de ser a conquista de um espaço de poder para as mulheres, mas em especial pelo componente de que as personagens representam mulheres lésbicas e negras. Isto é, para além do fator de exclusão social do gênero feminino, há o componente gay e o étnico enquanto agravantes de uma condição social constantemente inferiorizada em virtude dos muitos preconceitos existentes e que precisam ser superados. Desse modo, há um reverso positivo nessa situação e as personagens são delineadas como mulheres empoderadas.

Percebemos, então, que essa possibilidade literária de dar voz a minorias étnicas, de gênero e sociais aproxima a literatura homoerótica da literatura afro-brasileira, em especial da escrita afrofeminina, as quais se imbricam nas crônicas de Cidinha da Silva em Baú de mindezas, sol e chuva enquanto vozes que se fazem ouvir por meio das narrativas. Antonio Dias Silva (2014, p. 62) diz que, na literatura homoerótica, os espaços de poder se constroem quando as personagens dos textos "propagam imagens valorizando a si e aos outros da mesma subjetividade na relação físico-corporal, afetivo-sexual ou no trabalho, nas amizades [...], na crença religiosa". De modo correlato, podemos dizer que a mesma necessidade/situação de valorizar a si e aos seus ocorre também na literatura afro-brasileira.

De acordo com Lívia Maria Santos (2011), conjuntamente à tradição literária há literaturas de "sobrenomes" que buscam seu espaço de afirmação: 
[...] a literatura tem sobrenomes, e são muitos: homoafetiva, feminina, negra, periférica, oral. Cada um deles engendra um campo de diferenças constantemente silenciadas e caminham na contra mão, pela afirmação da diferença e negação da identidade unívoca uma vez que ela corresponde àquele que se pensa como o neutro, o apaziguador, o não-marcado que, ao fim e ao cabo, nada mais é que uma simulação de presença pura, igual a si mesmo que só admite ladear-se de outros objetos narcisicamente interiorizados, literaturas sem marcas, sem sobrenomes, mas com nomes próprios potentes o suficiente para solapar qualquer diferença (SANTOS, 2011, p. 111).

Assim, é possível observarmos que tanto a literatura afro-brasileira quanto a homoerótica caracterizam, confrontam e se afirmam como novos espaços plurais para o engendramento de questões relacionadas às minorias silenciadas durante séculos. Essas literaturas se configuram como mais uma possibilidade de leitura do mundo, abertas também a abrigarem os estudos biográficos, numa constante inter-relação entre o ficcional e o vivido, conforme enuncia Conceição Evaristo (2011b, p. 131): “Acredito que determinadas experiências forjam escritas ora mais, ora menos contaminadas pela condição biográfica do autor e do drama existencial enfrentado por ele".

Quando Cidinha da Silva oferta, então, aos seus leitores o seu Baú de mindezas, sol e chuva, ela possibilita que eles se deparem com as miudezas cotidianas, permeadas pela alegria do sol e pelo nublado da chuva, numa compreensão do pleno caráter de humanidade que acompanha as suas narrativas. O duplo não é antagônico do ser: é preciso desdobra-se para transformar-se. Ao reelaborar suas memórias e percepções de sujeito autoral, com base nas experiências vividas, e ficcionalizar em narrativas a "vida como ela é", pequenos fragmentos de subjetividade flertam com as crônicas e se inscrevem como pistas biografemáticas numa escrita afrofeminina vinculada à literatura afro-brasileira e à homoerótica. A cada texto, uma miudeza, seja de sol ou de chuva, é revelada e, em todas elas, mesmo nas dolorosas, sobrepõe-se o amor.

Aberto o baú de miudezas, resta ao leitor mergulhar nas histórias, memórias, lembranças, percepções e delas compreender a constante temática que perpassa as crônicas de Cidinha: somos feitos de miudezas de amor e de respeito. Nesses espaços de poder que se constroem a partir da resistência, o eu narrativo, de muitas características, reafirma seu 
pertencimento ético e étnico em defesa das minorias, num claro assumir de identidade, pois a voz que se faz ouvir é de um coletivo de mulheres negras e lésbicas, com um lindo baú de miúdas histórias a encantar o mundo. Em cada texto, essa voz autoral reclama, ao tempo em que conscientiza, que, independente de etnias e gêneros, somos todos miudezas de amor numa sociedade que pode e deve ser mais justa, plural e diversa.

\section{EN EL BAÚ DE MIUDEZAS DE CIDINHA DA SILVA, UNA ESCRITA AFRO-FEMENINA BIOGRAFEMÁTICA Y HOMOERÓTICA.}

RESUMEN: En Baú de miudezas, sol e chuva, publicado en 2014, Cidinha da Silva, por medio de una escrita afro-femenina, presenta en la narrativas, ficción y rasgos biográficos que se relacionan, conduciendo a las hibridas fronteras de los géneros discursivos y, también, se los desvelan una escrita biografemática y homoerótica, con base en las relaciones homoafetivas lesbianas entre mujeres negras. A partir de los textos, objetivamos analizar la escrita afro-feminina, pues que defendemos que, entre los biografemas presentados, hay una confluencia entre las vivencias biográficas de la autora y su escrita literaria, así como son revelados a los lectores detalles que conducen a la temática homocultural, a par de las relaciones lesbianas abordadas. Nos basamos en la crítica-teórica existente cuanto a los estudios biográficos y homoculturales, pero también en la literatura afro-brasileña. Hemos concluido previamente en ese estudio de metodología cualitativa de carácter bibliográfico que los biografemas posibilitan entrever tanto la construcción de un amor homoerótico femenino cuanto discusiones de género y etnia, que abordan también el empoderamiento de mujeres negras.

PALABRAS-CLAVE: Estudios biográficos; Homocultura; Literatura Afro-Brasileña.

\section{REFERÊNCIAS}

AUGRAS, Monique. O duplo e a metamorfose: a identidade mítica em comunidades nagô. Petrópolis, RJ: Vozes,2008.

ARFUCH, Leonor. O espaço biográfico: dilemas da subjetividade contemporânea. Tradução de Paloma Vidal. Rio de Janeiro: EdUERJ, 2010.

BARTHES, Roland. Sade, Fourier, Loyola. Trad. de Mário Laranjeira. São Paulo: Brasiliense, 1990.

DUARTE, Constância Lima. Cidinha da Silva. In: DUARTE, Eduardo Assis (org.). Literatura e afrodescendência no Brasil: antologia crítica. vol. 3 - Contemporaneidade. Belo Horizonte: Ed. UFMG, 2014.

DUARTE, Eduardo de Assis. Literatura afro-brasileira: um conceito em construção. In: Estudos de Literatura Brasileira Contemporânea, nº. 31. Brasília, janeiro-junho de 2008, p. 11-23. 
EVARISTO, Conceição. Literatura e educação segundo uma perspectiva afro-brasileira. In: EVARISTO, Conceição; SILVA, Denise Almeida (org.). Literatura, história, etnicidade e educação: estudos nos contextos afro-brasileiro, africano e da diáspora africana. Frederico Westphalen: URI, 2011a.

. Literatura negra: uma poética de nossa afrobrasilidade. In: EVARISTO, Conceição; SILVA, Denise Almeida (org.). Literatura, história, etnicidade e educação: estudos nos contextos afro-brasileiro, africano e da diáspora africana. Frederico Westphalen: URI, 2011b.

GOMES, Nilma Lino. Sem perder a raiz: corpo e cabelo como símbolos da identidade negra. Belo Horizonte: Autêntica, 2006.

FRY, Peter Henry. Para inglês ver: identidade e política na cultura brasileira. Rio de Janeiro: Zahar, 1982.

MITIDIERI, André Luís. Faces camp de Eva Perón para um biografema homocultural. In: Memórias da Borborema 5: Arquivos literários e escrita de si. Ana Cristina Marinho (Org.). - Campina Grande: Abralic, 2014. p. 97-112.

SANTOS, Lívia Maria Natália de Souza. Poéticas da diferença: a representação de si na lírica afro-feminina. In: A cor das letras: literatura, cultura e memória negra. $\mathrm{n}^{\circ}$ 12, UEFS, 2011, p. 105-124.

SILVA, Antonio Páduas Dias da. Uma visada sobre a construção discursiva em torno da temática homoerótica. In: GUSMÃO, S. D.; ALMEIDA, M. L. L.; PEREIRA, T. M. A. (orgs.). Gêneros e linguagens: diálogos abertos. João Pessoa: Editora Universitária da UFPB, 2009.

- A literatura brasileira de temática homoerótica e a escrita de si: literatura homoerótica e escritas de si. In: Acta Scientiarum: Language and Culture. Maringá, v. 36, n. 1, p. 61-71, Jan.-Mar., 2014.

SILVA, Cidinha da. Baú de miudezas, sol e chuva: crônicas. Belo Horizonte: Mazza Edições, 2014.

VERGER, Pierre Fatumbi. Fluxo e Refluxo do tráfico de escravos entre o Golfo do Benin e a Babia de Todos os Santos dos Séculos XVII A XIX. 4 ed. rev. Salvador: Corrupio, 2002.

Recebido em: 29/09/2017.

Aprovado em: 08/12/2017. 